\title{
THE EFFECT OF THE SARBANES-OXLEY ACT AND CD\&A RULE ON COMPENSATION STRUCTURE AND HEDGING DECISION OF CROSS-LISTED FIRMS
}

\author{
Chialing Hsieh, The University of Texas at Tyler, U.S.A. \\ Jasmin Lin, Robert Morris University, U.S.A.
}

dx.doi.org/10.18374/IJBR-20-3.6

\begin{abstract}
This study explores possible effects of seeking to impose rules on cross-listing firms that are already subject to equivalent or superior measures under their domestic regime. We expect that cross-listed firms (particularly when they are located in English legal origin countries) will alter the performance-based compensation to fixed compensation awarded to corporate executives under increased regulation scrutiny by SOX and CD\&A Rule. Moreover, SOX enhanced transparency and disclosure of derivatives use may lower cross-listed firms' incentives to hedge, particularly for firms located in English legal origin countries with stronger country-level governance.
\end{abstract}

Keywords: Compensation; Hedging; Sarbanes-Oxley Act 